\author{
Military Technical College \\ Kobry El-Kobbah, \\ Cairo, Egypt.
}

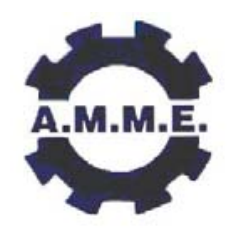
$13^{\text {th }}$ International Conference on Applied Mechanics and Mechanical Engineering.

\title{
EVALUATION OF CO-GENERATION AND TRI-GENERATION SYSTEMS EMPLOYING RECIPROCATING AND GAS TURBINE ENGINES FOR POWER GENERATION
}

\author{
ELKADY $^{*}$ E.A., SAID ${ }^{* *}$ S.A. and ELKADY*** M.A.
}

\begin{abstract}
The present investigation is a trial to tackle the problem of energy rationalization in power generation. It is believed that such target can be reached through employment of tri-generation system for combined heating, cooling and power production (CHCP). The power range selected for the present study is from few hundreds kilowatt to five megawatts electric demand. The present study investigates four arrangements to select the best solution to achieve the requirements of power, cooling load, and/or heating load for various applications. These arrangements include tri-generation, cogeneration with heating, cogeneration with cooling, and separate unit arrangement.
\end{abstract}

A computer program was developed in the present investigation using Lab-View graphical language. The developed computer code allows the selection of the most economical power generating system to satisfy given requirements of electric, heating and cooling loads. Moreover, the program model can determine the optimal strategies that minimize the overall cost of energy for the CHCP system.

A comparison between the economics of each arrangement was conducted in terms of total cost saving ratio (TCSR). This comparison revealed a saving ranging from $15 \%$ to $25 \%$ of the total cost of the separate units arrangement within five years by using cogeneration or tri-generation arrangements. This saving is associated with the employed energy rationalization technique, which is defined in terms of the primary energy saving ratio (PESR). Cogeneration and tri-generation arrangements proved to be able to achieve primary energy saving ratios ranging from $25 \%$ to $30 \%$.

\section{KEY WORDS}

Cogeneration - tri-generation - reciprocating engines - solar fueled gas turbines - tons of refrigeration - energy efficiency ratio.

* Associate Prof., ${ }^{* *}$ M.Sc Applicant and ${ }^{* * *}$ Professor, Mech. Eng. Dept., Faculty of Engineering, Al-Azhar University, Nasr City, Cairo, Egypt. 


\section{INTRODUCTION}

In order to sustain economic development, the growing electrical demand must be met. The classic way to meet the demand is to build additional electricity generating stations.. Another way to help meet the demand is electrical energy conservation, which is also under way throughout Egypt, especially in the industrial sector [1]. A third solution is the energy rationalization

The main cogeneration potential in tertiary sector is in hospitals, hotels, sports centers, office buildings, shopping centers and district heating systems. The choice of the most appropriate cogeneration technology depends on a series of factors, such as the heat/electricity ratio, the temperature levels of the heat required, the fuel availability, fluctuations in thermal demand,..... etc. Gas reciprocating engines and micro-turbines, together with absorption cooling plants are the technologies currently being used in trigeneration systems in the tertiary sector of a temperature climate area [2].

As for the first stage of a preliminary feasibility study, it is very important to analyze the energy demands of the consumer. All energy saving measures should have been taken, prior to sizing a CHP system. A detailed study should also be carried out on possible increases in demand, its time scale, and thermal and electric energy consumption structure. Factors such as operating times, available fuels, ......etc., have to be kept in mind during all these evaluations. Once the current situation has been determined, a decision needs to be taken on the most suitable installation for the particular case, such as: gas turbines, reciprocating engines etc. Hence the components of tri-generation system must be analyzed technically and economically to develop an optimization program model to facilitate the selection of optimum solution for the consumer.

The basic part which characterizes the plant of a tri-generation installation is the CHP unit that produces electricity and heat. The second most important part is the absorption chiller, which produces cooling by utilizing the heat of the cogeneration process. Those two components will be presented separately in this paper. The analysis including a comparison between the different prime movers to select the most economical power generating system to satisfy given requirements of electric, heating , and cooling loads. The selection and the matching between the different components are completed by using the graphical Lab-View. The present work investigates the variation of the primary energy saving ratio (PESR) and the total cost saving ratio (TCSR) for different arrangements with electric load of 1000 to $5000 \mathrm{~kW}$ to select the best solution among various arrangements. A schematic layout of the four principles of the cases under investigation are shown in Fig. (1 to 4).

\section{RECIPROCATING INTENAL COMBUSTION ENGINES ICE}

This section includes the performance and cost of reciprocating engine systems for two primary applications. The first is for systems designed to produce power only. Systems configured for this purpose could be used in a variety of applications including standby power, peaking, and grid support. The second configuration is combined heat and power (CHP), where additional equipment is added to the basic engine to allow recovery and subsequent use of jacket cooling and exhaust heat in industrial processes or commercial buildings. While CHP systems have many of the characteristics of 
power-only systems, they have additional complexity and require design tradeoffs that are described in this section.

Table (1) provides an overview of the performance characteristics and cost of typical reciprocating engine systems commercially available in 2003. The performance characteristics are given in the top part of the table and applied to both power-only and CHP applications. Table 1 covers a power range from $100 \mathrm{~kW}$ to $5 \mathrm{MW}$, which represents the majority of the market applications for engine-driven power-only and CHP applications [3]. The heat rates and efficiencies shown were taken from manufacturer's specifications and industrial publications [4]. Available thermal energy was calculated from published data on engine exhaust temperatures and engine jacket and lube system coolant flows. CHP thermal recovery estimates are based on producing hot water for process or space-heating needs.

The data in table (1) show that electrical efficiency increases as engine size becomes larger. As electrical efficiency increases, the absolute quantity of thermal energy available to produce useful thermal energy decreases per unit of power output, and the ratio of power to heat for the CHP system generally increases. For the diesel engine, the absolute quantity of thermal energy available to produce useful thermal energy per unit of power output, and the ratio of power to heat for the CHP system remained constant. A change in the heat to power ratio may divert project economics and consequently, customer decision will depend on some other factors such as the possibility of selling power [3]

Energy in the fuel is released during combustion and is converted to shaft work and heat. Shaft work drives the generator while heat is liberated from the engine through coolant, exhaust gas, and surface radiation. Approximately $60-70 \%$ of the total energy input is converted to heat that can be recovered from the engine exhaust and jacket coolant; while smaller amounts are also available from the lube oil cooler and the turbocharger's intercooler and after cooler (if so equipped). Steam or hot water can be generated from recovered heat that is typically used for space heating, reheat, domestic hot water and absorption cooling. Heat in the engine jacket coolant accounts for up to $30 \%$ of the energy input and is capable of producing about $93.3^{\circ} \mathrm{C}$ hot water. Some engines, such as those with high pressure or ebullient cooling systems, can operate with water jacket temperatures up to about $129.4^{\circ} \mathrm{C}$ [5].

Engine exhaust heat is $10-30 \%$ of the fuel input energy. Exhaust temperatures are in the range of 454.4 to $649^{\circ} \mathrm{C}$ are typical. Only a portion of the exhaust heat can be recovered since exhaust gas temperatures are generally kept above condensation thresholds. Most heat recovery units are designed for a range of 149 to $176.7^{\circ} \mathrm{C}$ exhaust outlet temperature to avoid the corrosive effects of condensation in the exhaust piping. Exhaust heat is typically used to generate hot water at about $110^{\circ} \mathrm{C}$ or lowpressure steam at 1.0342 bars. By recovering heat in the jacket water and exhaust, approximately $70-80 \%$ of the fuel's energy can be effectively utilized to produce both power and useful thermal energy [5].

Capital cost for two configurations are presented namely, power-only and CHP. Capital costs (equipment and installation) are estimated for the five typical reciprocating engine genset systems ranging from $100 \mathrm{~kW}$ to $5 \mathrm{MW}$ for each configuration. These are "typical" budgetary price levels. It should also be noted that installed costs vary significantly depending on the scope of the plant equipment, geographical area, 
competitive market conditions, special site requirements, emissions control requirements, prevailing labor rates, and whether the system is a new or retrofit application [8].

Table (2) provides cost estimates for current power-only systems. The estimates are based on a simple installation with minimal site preparation required.

Table (3) shows the cost estimates on the same basis for combined heat and power applications. The CHP systems are assumed to produce hot water, although the multimegawatt size engines are capable of producing low-pressure steam. The heat recovery equipment consists of an exhaust heat exchanger that extracts heat from the exhaust system, a process heat exchanger that extracts heat from the engine jacket coolant, a circulation pump, a control system, and piping. The CHP system also requires additional engineering to integrate the system with the on-site process.

Maintenance costs vary with type, speed, size and number of cylinders of an engine and typically include; maintenance labor, engine parts and material such as oil filters, air filters, spark plugs, gaskets, valves, piston rings, electronic components,... etc. as well as consumables such as oil and minor and major overhauls.

Table (4) presents maintenance costs based on engine manufacturer estimates for service contracts consisting of routine inspections and scheduled overhauls of the engine generator set. Costs are based on 8,000 annual operating hours expressed in terms of annual electricity generation.

\section{ABSORPTION COOLING}

Absorption chillers use heat, instead of mechanical energy, to provide cooling. Compared to mechanical chillers, absorption chillers have a low coefficient of performance . Nonetheless, they can substantially reduce operating costs because they are energized by low-grade waste heat, while vapor compression chillers must be motor- or engine-driven. Low-pressure, steam-driven absorption chillers are available in capacities ranging from 100 to 1,500 tons of refrigeration (T.R.). Absorption chillers come in two commercially available designs: single-effect and double-effect. Singleeffect machines provide a thermal COP of 0.7 and require about $8.16 \mathrm{~kg}$ at about 1 bar steam per ton-hour of cooling. Double-effect machines are about 40 percent more efficient, but require a higher grade of thermal input, using about $4.536 \mathrm{~kg}$ at about 6.5 to 10 bars steam per ton-hour [8].

For absorption cooling systems having water - $\mathrm{LiBr}$ working pair, the heat source (calorific energy discharged from the cogeneration system, in principle) must be at a minimum temperature of $60-80^{\circ} \mathrm{C}$, or as high as $150^{\circ} \mathrm{C}$ if considered a double-effect system. For the systems that use ammonia as a refrigerant the requirement of a heat source is $100-120^{\circ} \mathrm{C}$ (single effect system) [2].

Table (5) provides an overview of performance characteristics of typical fuel driven absorption chiller in the range of 40 T.R. to 1100 T.R. These can be "fired" with oil fuel based on gross calorific value $46816 \mathrm{~kJ} / \mathrm{kg}$ and $43263 \mathrm{~kJ} / \mathrm{kg}$ for the gas fuel. This table considered a double effect absorption chiller, which has COP ranged from 1.08 to 1.14 [9]. 
Table (6) summarizes performance characteristics for typical commercially available single effect hot water absorption chillers over the 10 to 1400 T.R. size range. The COP of the hot water driven absorption chiller is about 0.7 based on the temperature in the hot water circuit is $90.6 / 85^{\circ} \mathrm{C}$ [9].

Table (7) covers the majority of the market applications for steam driven absorption chiller systems over the 100 to 1400 T.R. size range. These units can be "fired" with steam at 1.5 to 8 bar gage, which corresponds to a steam temperature of 111 to 170 ${ }^{\circ} \mathrm{C}$. The lower temperature value is employed for the single effect, while the higher value is used for the double effect chiller. The COP is in the range from 0.6 to 0.7 for the single effect, and from 0.9 to 1.1 for the double effect absorption chiller [9].

In many commercial facilities that require air conditioning, chillers are major energy consumer units. Thus, it is important to select a chiller that costs as little as possible to operate for the specific application. Facility managers and maintenance planners should take care to select equipment with the lowest life cycle cost rather than simply the lowest purchase price. The cost of energy for chillers over their life is usually many times the initial capital expense.

The Capital cost for the absorption chillers of various capacities is shown in table (8).The average annual maintenance cost of modern single-effect indirect absorption chillers is fairly close to $\$ 18$ to $\$ 28$ per ton of cooling capacity [10 - 12].

\section{RESULTS AND DISCUSSION}

Now, after knowing all the technical and economical data, the selection of the best solution from the tri-generation, cogeneration with heating, and cogeneration with cooling, or separation system and also, the selection of the economic prime mover can be attained. However, it has been proved to be difficult and time consuming to treat the large amount of data available. To facilitate the treatment process a new computer program has been developed using a computer language called Lab-View [13].

The present study investigates the viability of applying cogeneration and tri-generation principles. The power range selected for the present study is from few hundreds of kilowatt to five megawatts. This range encompasses various power generating systems. The power generating systems considered in the present work are the gas engine, the diesel engine. Results obtained from the computer aided data analysis using the developed program are plotted in figures 5 through 10 for reciprocating gas engines, and from 11 to 14 for comparison between different power generating systems.

\section{Primary Energy Saving Ratio (PESR)}

The primary energy saving ratio is defined as the difference between primary energy input for separate unit system and that for tri-generation or cogeneration system, divided by the primary energy input for separate unit system [14]. In spite of the fact that PESR indicates the percentage of energy saved by tri-generation or cogeneration arrangement, it does not imply that this arrangement is the most economical one. The results presented in this section show the variation of PESR with heating load for a gas engine with various cooling and electric loads. 
Fig. 5 shows the variation of the primary energy saving ratio (PESR) with the heating load for different values of cooling loads for the tri-generation arrangement with electric load of $5000 \mathrm{~kW}$. It is observed that the PESR increases with the increases of the heating load because of the increase in the amount of the heat recovered. It is noticed that, the maximum value of PESR is reached when the heat to power ratio requirements are equal to the heat to power ratio of the engine. This is due to the fact that the system has used all the recoverable heat produced by the engine. It is also observed that the value of PESR begins to decrease where the heat requirements exceed the heat recoverable from the engine. It can also be detected that the PESR in the left side of the curves increases with the increase of the cooling load until reaching the heat to power ratio of the engine then, the PESR starts decreasing with the increasing of the cooling load. This is due to the same reasons discussed before. Nevertheless, the other side of the curves shows that the PESR decreases with the increase of the cooling load. This may be attributed to the fact that the heat requirements exceed the heat recoverable from the engine. The peak value of PESR for 100 T.R. cooling load curve is higher than that for 300 T.R., this may be explained by knowing that the input energy of the direct effect absorption chiller is lower than that of the indirect effect type, for the same cooling load.

Figure 6 shows the variation of the heating load with the PESR for different values of the electric load with constant value of cooling load. It is noticed that the PESR decreases with the increase of the electric load at low values of heating load because the system does not use all the heat recoverable from the high electric power engine. With further increase of the heating load PESR increases due to the ability of using high amount of heat recoverable from the high electric power engine. It is also observed that the $5000 \mathrm{~kW}$ electric load curve starts to decrease after the $3000 \mathrm{~kW}$ curve this is due to the fact that the heat recoverable from the $5000 \mathrm{~kW}$ engine is higher than that of the $3000 \mathrm{~kW}$ engine.

Figure 7. shows the variation of PESR with the heating load for the different arrangements at $5000 \mathrm{~kW}$ electric power and 500 T.R. cooling load. It can be noticed that in the left side of the curves where the heating load is having low value leads to minimum values of PESR for the cogeneration with heating arrangement. This is due to the lower amount of heat load compared to the heat recoverable from the engine. On the other hand the tri-generation arrangement has the maximum PESR for these low values of heating load. This indicates that tri-generation of these load requirements offers the best energy saving option. Nevertheless, the right side of figures for which the heating load values are higher, the cogeneration with heating yields the maximum PESR values.

\section{Total Cost Saving Ratio (TCSR)}

The above mentioned discussions of the plotted values of PESR for various load requirements and power generation arrangements reveal a comparison between these requirements and arrangements from the point of view of energy saving. However, saving energy does not mean, in all cases, the most economical option. Therefore, it is necessary to investigate the economical aspect of these arrangements. The total cost saving ratio (TCSR), defined as the difference between the total cost of separate units and the total cost of tri-generation or cogeneration arrangements, divided by the total cost of separate units, is used as an indicator of this economical aspect. 
Figure 8 shows the variation of the total cost saving ratio (TCSR) with the heating load for different values of cooling loads for the tri-generation arrangement with electric load of $5000 \mathrm{~kW}$. It is observed that the TCSR increases with the increases of the heating load because of the increase in the amount of heat recovered which increases the primary energy saving ratio and accordingly increases the total cost saving ratio. It is also noticed that, the maximum value of TCSR is reached when the heat to power ratio requirements are equal to the heat to power ratio of the engine so, maximum PESR matches with maximum TCSR. This is due to the fact that the system has used all the recoverable heat produced by the engine. It is also observed that, the value of TCSR begins to decrease when the heat requirements exceed the heat recoverable from the engine hence, low value of PESR is attained. In addition, it can be detected that the TCSR in the left side of the curves increases with the increase of the cooling load until reaching the heat to power ratio of the engine and so, (maximum PESR) then, the TCSR starts decreasing with the increase of the cooling load. This is due to the same reasons discussed before. Nevertheless, the other side of the curves shows that the TCSR decreases with the increase of the cooling load. This may be attributed to the fact that the heat requirements exceed the heat recoverable from the engine and the lower values of PESR. The peak value of TCSR for 100 T.R. cooling load curve is higher than that for 300 T.R., this may be explained by knowing that the PESR for the 100 T.R. curve is higher than that of the 300 T.R. curve, for the same electric load.

Figure 9. shows the variation of the heating load with the TCSR for different values of the electric load with constant value of cooling load. It is noticed that, TCSR decreases with the increase of the electric load at low values of heat requirement because the system does not use all the heat recoverable from the high power engine and therefore low value of PESR is attained. With further increase of the heat requirements TCSR increases due to the possibility of using higher amount of the recoverable heat from the high power engine, and hence higher values of PESR. It is also observed that, the 5000 $\mathrm{kW}$ electric load curve starts to decrease after the $3000 \mathrm{~kW}$ curve. This is due to the fact that the PESR of the $5000 \mathrm{~kW}$ engine is higher than that of the $3000 \mathrm{~kW}$ engine at high heating loads values.

Figure 10 shows the variation of TCSR with the heating load for the different arrangements at $5000 \mathrm{~kW}$ electric power and 500 T.R. cooling load. It can be noticed that in the left side of the curves where the heating load is having low value, this leads to minimum values of TCSR for the cogeneration with heating arrangement. This is due to the lower amount of heat load compared to the heat recoverable from the engine and so, the cogeneration with heating has lower PESR at this range of heating loads. On the other hand the tri-generation arrangement has the maximum TCSR for these low values of heating load. This indicates that tri-generation of these load requirements offers the best cost saving option. Nevertheless, the right side of figures for which the heating load values are higher, the cogeneration with heating yields the maximum TCSR values.

\section{Comparison Between Various Prime Movers}

In this section a comparison between gas engine, diesel engine and gas turbine from the point of view of its performance and economy in a tri-generation and cogeneration arrangements, is conducted. To carry out this comparison, similar economic and technical analyses were conducted for all these prime movers ( see Ref. [15] for more details). 
It can be detected from figure.11 that the diesel engine has the higher PESR when the heat to power ratio equals 1.1 or less and this is due to that it has the minimum waste heat recoverable and lower input energy than the other engines. When the heat to power ratio enclosed between 1.1 up to 1.5 the gas engine will be having the maximum PESR because it has heat to power ratio higher than that of the diesel engine, and although the gas turbine has the higher heat to power ratio, not all the recoverable heat has been utilized. With further increase in the heat to power ratio over 1.5, the gas turbine will be having the maximum PESR because the gas turbine has sufficient recoverable heat to achieve the requirements of the system.

Figure 12 shows that in the left side of the curves the diesel engine has the maximum TCSR and this may be attributed to the fact that, it has the maximum PESR if compared with the other engines, the cost of the solar fuel is higher than the natural gas fuel and it has the lower input energy per kW power output. On the other hand the gas engine has TCSR higher than the gas turbine and this may be due to the lower initial cost of the gas engine and the higher PESR of the gas engine compared with the gas turbine.

In the right side of figure 12 , it is noticed that the gas turbine has the maximum TCSR and this is because it has the maximum primary energy saving ratio at higher heat load requirements. Although, the diesel engine in this range of heat load has lower PESR than the gas engine, however, it has TCSR higher than the gas engine because the cost of solar fuel is higher than the N.G. fuel.

Figure 13 shows the variation of the heat recovery with the TCSR for different values of the electric loads for gas engine, diesel engine and gas turbine. It can be shown that at low heat load values the low electric power prime mover has TCSR higher than the high electric power one because it has the maximum PESR, and this is reversed at the high values of heat loads.

Figure 14 shows the variation of the TCSR with the number of hours of operation for different prime movers and a cooling load of 100 T.R., an electric load of $3000 \mathrm{~kW}$ and a heating load of $5000 \mathrm{~kW}$. It can be detected that the TCSR increases with the increases of the number of hours of operation because of the progressively increasing amount of saved energy.

\section{CONCLUSIONS}

The results of the present work show clearly, tri-generation and cogeneration arrangements start to be economically viable if the operating time is higher than 5000 hours per year. However, tri-generation and cogeneration arrangements applications are recommended when the company requirements of heat to power ratios approach the heat to power ratio of the prime-mover.

The main conclusions which could be deduced from the results of the present work are outlined in the following points:

1. Applying tri-generation and cogeneration with heating arrangements saves about $25 \%$ to $30 \%$ of the energy consumed when using separate arrangement.

2. Applying cogeneration with cooling arrangement saves about $15 \%$ to $20 \%$ of the energy consumed when using separate arrangement. 
3. Tri-generation arrangement can save from $15 \%$ to $20 \%$ of the total cost of the separate arrangement within five years.

4. Cogeneration with heating arrangement can save from $20 \%$ to $25 \%$ of the total cost of the separate arrangement within five years. However, cogeneration with cooling arrangement has been proved to be uneconomical.

5. For low and medium electrical loads, diesel engine is more recommended than gas turbine, or gas engine as a primemover. However, for high electrical loads, solar fueled gas turbine proved to be the best choice as a primemover.

6. Tri-generation and cogeneration applications are more viable for solar fueled gas turbine, than natural gas fueled once.

7. It should be mentioned that the market at which the costs shown in tables are valid in the European market and the present work is considered as a comparative study.

\section{REFERENCES}

1. Hagler, Bailly, "Cogeneration", Energy Conservation and Environment Program, Project No. 263-0140, 1995.

2. Guo, W., "Promotion of Tri-Generation Technologies in the Tertiary Sector", European Commission, SAVE Program, Project No. 4.1031/Z/01-130/2001, 2003.

3. Hedman, B., Freedman, S. I., Knowles, D., "Gas-Fired Distributed Energy Resource Technology Characterizations", U.S. Department of Energy, National Renewable Energy Laboratory (NREL), October 2003.

4. Hedman, B. A., Darrow, K., Bourgeois, T., "Combined Heat and Power" , New York State Energy Research and Development Authority (NYSERDA), Final Report , October 2002.

5. Energy Nexus Group, "Technology Characterization Reciprocating Engines", EPA, February 2003.

6. Onsite Sycom Energy Corporation "Review of Combined Heat and Power Technologies", Office of Energy Efficiency and Renewable Energy, U.S. Department of Energy, October 1999.

7. Christofrides, A., "Combined Heat and Power Generation", European Commission , Directorate-General of Energy , SAVE II Programme, May 2001.

8. Office of Industrial Technologies (OITs), "Use Low-Grade Waste Steam to Power Absorption Chillers", U.S. Department of Energy, Tip Sheet 14, May 2001.

9. THERMAX Co., "Absorption Chiller Catalogue", 10 - 1400 ton absorption chiller, 2005.

10. Ryan , W. , Cuttica J., Farrar, L., Haefke, C., "Cogeneration Analysis" , Uneversity of Illinois at Chicago, Energy Resources Center, June 2001.

11. Hudson, R., "Survey of DER/CHP Software", Oak Ridge National Laboratory , U.S. Department of Energy , February 2003.

12. Energy Efficiency and Renewable Energy Center, "Economic and Financial Assessments", University of Massachusetts Amherst, March 2005.

13. LabVIEW 6.1 graphical programming for Instrumentation, National Instruments Corporate Headquarters, 2003.

14. Uche, J., Serra, L., Sanz, A., "Integration of Desalination with Cold-Heat-Power Production in the Agro-Food Industry", Desalination, Volume 166, Pages 379-391, February 2004.

15. Aly,S.,"Energy Rationalization For Air Conditioning System", M.Sc. Thesis Submitted to Al-Azhar University, 2007. 
Table (1) Reciprocating engine CHP - typical performance parameters

\begin{tabular}{|c|c|c|c|c|c|c|c|c|c|c|}
\hline & \multicolumn{5}{|c|}{ Natural gas reciprocating engine [5] } & \multicolumn{5}{|c|}{ Diesel engine[6],[7] } \\
\hline Baseload Electric Capacity (kW) & 100 & 300 & 800 & 3,000 & 5,000 & 100 & 300 & 800 & 3,000 & 5,000 \\
\hline Electric Heat Rate (kJ/kWh), HHV & 11,147 & 10,967 & 10,246 & 9,492 & 8,758 & 9,585 & 9,452 & 8,909 & 8,322 & 7,755 \\
\hline $\begin{array}{l}\text { Installed Cost - Power Only } \\
(\$ / \mathrm{kW})\end{array}$ & 1,030 & 790 & 740 & 710 & 695 & 775 & 600 & 555 & 530 & 520 \\
\hline Installed Cost - CHP $(\$ / k W)$ & 1,350 & 1,160 & 1,006 & 935 & 890 & 1,350 & 1,160 & 1,006 & 935 & 890 \\
\hline Fuel Input (MMkJ/hr) & 1.11 & 3.29 & 8.20 & 28.48 & 43.79 & 0.96 & 2.84 & 7.13 & 25.00 & 38.78 \\
\hline $\begin{array}{l}\text { Required Fuel Gas Pressure } \\
\text { (barg) }\end{array}$ & $<0.2$ & $<0.2$ & $<0.2$ & 2.92 & 4.42 & \multicolumn{5}{|c|}{$<0.4$} \\
\hline \multicolumn{11}{|l|}{ CHP Characteristics } \\
\hline Exhaust Flow (kg/hr) & 453 & 1494.9 & 4937.7 & 21925 & 30396 & \multicolumn{5}{|c|}{ N. A. ${ }^{*}$} \\
\hline $\begin{array}{l}\text { Useable Temperature for } \mathrm{CHP} \\
\left({ }^{\circ} \mathrm{C}\right)\end{array}$ & \multicolumn{5}{|c|}{$150-260$} & \multicolumn{5}{|c|}{$82-482$} \\
\hline $\begin{array}{l}\text { Heat Recovered from Lube } \\
\text { System (MMkJ/hr) }\end{array}$ & 0 & 0 & 0.29 & 1.22 & 1.94 & 0 & 0 & 0 & 1.24 & 1.98 \\
\hline Total Heat Recovered (MMkJ/hr) & 0.57 & 1.51 & 3.50 & 11.12 & 15.38 & 0.34 & 1.03 & 2.73 & 10.24 & 17.06 \\
\hline Total Heat Recovered (kW) & 167 & 443 & 1,025 & 3,259 & 4,508 & 100 & 300 & 800 & 3,000 & 5,000 \\
\hline Form of Recovered Heat & \multicolumn{5}{|c|}{ Hot H2O } & \multicolumn{5}{|c|}{ Hot H2O } \\
\hline Total Efficiency (\%) & $81 \%$ & $77 \%$ & $76 \%$ & $75 \%$ & $74 \%$ & $71.2 \%$ & $72.2 \%$ & $76.6 \%$ & $82.0 \%$ & $88.0 \%$ \\
\hline Power/Heat Ratio & 0.60 & 0.68 & 0.78 & 0.92 & 1.11 & \multicolumn{5}{|c|}{1.00} \\
\hline Net Heat Rate (KJ/kWh) & 4,063 & 4,687 & 4,774 & 4,857 & 4,914 & 5,320 & 5,187 & 4644 & 4057 & 3490 \\
\hline Effective Electric Efficiency & $\begin{array}{c}84.0 \\
\%\end{array}$ & $72.8 \%$ & $71.5 \%$ & $70.2 \%$ & $69.4 \%$ & $64.1 \%$ & $65.8 \%$ & 73.5 & $84.1 \%$ & $97.7 \%$ \\
\hline
\end{tabular}

N. A. : Not Available: 
Table (2) Estimated capital cost for typical reciprocating engine-generators in gridinterconnected power-only applications (2003) [3]

\begin{tabular}{|c|c|c|c|c|c|}
\hline Cost Component & $\begin{array}{c}\text { System } \\
1\end{array}$ & $\begin{array}{l}\text { System } \\
2\end{array}$ & $\begin{array}{c}\text { System } \\
3\end{array}$ & $\begin{array}{c}\text { System } \\
4\end{array}$ & $\begin{array}{l}\text { System } \\
5\end{array}$ \\
\hline $\begin{array}{l}\text { Nominal Capacity (kW) } \\
\text { Cost }(\$ / k W) \\
\text { Equipment }\end{array}$ & 100 & 300 & 800 & 3000 & 5000 \\
\hline $\begin{array}{l}\text { Genset Package } \\
\text { Interconnect/Electric }\end{array}$ & $\begin{array}{l}400 \\
250\end{array}$ & $\begin{array}{l}350 \\
150\end{array}$ & $\begin{array}{l}365 \\
115\end{array}$ & $\begin{array}{c}440 \\
75\end{array}$ & $\begin{array}{c}450 \\
65\end{array}$ \\
\hline Total Equipment & 650 & 500 & 480 & 515 & 515 \\
\hline Labor/Materials & 228 & 175 & 150 & 103 & 103 \\
\hline Total Process Capital & 878 & 675 & 630 & 618 & 618 \\
\hline $\begin{array}{l}\text { Project, Construction } \\
\text { and Management }\end{array}$ & 66 & 50 & 48 & 40 & 25 \\
\hline Engineering and Fees & 53 & 40 & 38 & 26 & 26 \\
\hline Project Contingency & 33 & 25 & 24.3 & 26 & 26 \\
\hline Total Plant Cost $(2003 \$ / \mathrm{kW})$ & $\$ 1,030$ & $\$ 790$ & $\$ 740.3$ & $\$ 720$ & $\$ 695$ \\
\hline
\end{tabular}

Table (3) Estimated capital cost for typical reciprocating engine-generators in gridinterconnected CHP applications (2003) [3]

\begin{tabular}{|l|c|c|c|c|c|}
\hline \multicolumn{1}{|c|}{ Cost Component } & $\begin{array}{c}\text { System } \\
1\end{array}$ & $\begin{array}{c}\text { System } \\
2\end{array}$ & $\begin{array}{c}\text { System } \\
3\end{array}$ & $\begin{array}{c}\text { System } \\
4\end{array}$ & $\begin{array}{c}\text { System } \\
5\end{array}$ \\
\hline Nominal Capacity (kW) & 100 & 300 & 800 & 3000 & 5000 \\
Cost (\$/kW) & & & & & \\
Equipment & & & & & \\
$\quad$ Genset Package & 500 & 350 & 365 & 440 & 450 \\
$\quad$ Heat Recovery & Incl. & 180 & 115 & 65 & 40 \\
$\quad$ Interconnect/Electric & 250 & 150 & 115 & 75 & 65 \\
\hline Total Equipment & 750 & 680 & 595 & 580 & 555 \\
$\quad$ & 413 & 306 & 258 & 220 & 210 \\
\hline Labor/Materials & 1,163 & 986 & 853 & 800 & 765 \\
Total Process Capital & 75 & 70 & 60 & 58 & 55 \\
$\quad$ Project, Construction & 75 & 70 & 60 & 48 & 44 \\
and Management & 38 & 34 & 30 & 28 & 28 \\
\hline Engineering and Fees & $\$ 1,350$ & $\$ 1,160$ & $\$ 1003$ & $\$ 935$ & $\$ 890$ \\
\hline Project Contingency & & & & & \\
\hline Total Plant Cost (2003 \$/kW) & & & & & \\
\hline
\end{tabular}


Table (4) Typical natural gas engine maintenance costs [3]

\begin{tabular}{|c|c|c|c|c|c|}
\hline $\begin{array}{l}\text { Operating and Maintenance } \\
\text { Costs }\end{array}$ & $\begin{array}{c}\text { System } \\
1\end{array}$ & $\begin{array}{l}\text { System } \\
2 \\
\end{array}$ & $\begin{array}{c}\text { System } \\
3\end{array}$ & $\begin{array}{c}\text { System } \\
4\end{array}$ & $\begin{array}{c}\text { System } \\
5\end{array}$ \\
\hline Nominal Capacity, kW & 100 & 300 & 800 & 3000 & 5000 \\
\hline $\begin{array}{l}\text { Variable (service contract), } \\
\$ / \mathrm{kWh}\end{array}$ & 0.017 & 0.012 & 0.0095 & 0.0083 & 0.0079 \\
\hline Fixed, \$/kW-yr & 10 & 5 & 4.28 & 1.5 & 1.1 \\
\hline Fixed, \$/kWh @ 8,000 hrs/yr & 0.00125 & 0.00063 & 0.00053 & 0.00019 & 0.00014 \\
\hline Total O\&M Costs, (\$/kWh) & 0.018 & 0.013 & 0.009 & 0.009 & 0.008 \\
\hline
\end{tabular}


Table (5) Fuel driven absorption chiller-heater - technical specifications [9]

\begin{tabular}{|c|c|c|c|c|c|c|c|c|}
\hline \multirow{3}{*}{$\begin{array}{c}\text { Nominal refrigeration } \\
\text { capacity }\end{array}$} & \multirow{2}{*}{ Cooling capacity } & NT.R. & 40 & 100 & 300 & 500 & 700 & 1100 \\
\hline & & $\mathrm{kW}$ & 140.4 & 352 & 1056 & 1760 & 2464 & 3872 \\
\hline & Heating capacity & kW & 107.2 & 322 & 957 & 1612 & 2254 & 3542 \\
\hline \multirow{2}{*}{ Chilled water circuit } & Flow rate & $\mathrm{m}^{3} / \mathrm{h}$ & 22.0 & 55.0 & 164.9 & 302.4 & 384.9 & 604.8 \\
\hline & Inlet/ Outlet temp. (Cooling) & ${ }^{\circ} \mathrm{C}$ & \multicolumn{6}{|c|}{$12.2 / 6.7$} \\
\hline \multirow{2}{*}{ Hot water circuit } & Flow rate & $\mathrm{m}^{3} / \mathrm{h}$ & 16.0 & 49.0 & 148 & 247 & 346 & 544 \\
\hline & Hot water inlet / Outlet temp. & ${ }^{\circ} \mathrm{C}$ & \multicolumn{6}{|c|}{$54.4 / 60$} \\
\hline \multirow{2}{*}{ Cooling water circuit } & Flow rate (Cooling) & $\mathrm{m}^{3} / \mathrm{h}$ & 40 & 96 & 288 & 480 & 700 & 1100 \\
\hline & Inlet/ Outlet temp. (Cooling) & ${ }^{\circ} \mathrm{C}$ & \multicolumn{6}{|c|}{$29.4 / 34.7$} \\
\hline \multirow{6}{*}{ Fuel circuit } & Rated heat input (Cooling) & $\mathrm{kW}$ & 130 & 309 & 926 & 1544 & 2161 & 3396 \\
\hline & Oil consumption (Cooling) & $\mathrm{Kg} / \mathrm{h}$ & 10.0 & 23.8 & 71.2 & 119 & 166.2 & 261.2 \\
\hline & Gas consumption (Cooling) & $\mathrm{m}^{3} / \mathrm{h}$ & 11.6 & 27.6 & 82.7 & 138 & 193 & 303 \\
\hline & Rated heat input (Heating) & $\mathrm{kW}$ & 130 & 354 & 1061 & 1768 & 2471 & 3884 \\
\hline & Oil consumption (Heating) & $\mathrm{Kg} / \mathrm{h}$ & 10.0 & 27.3 & 81.6 & 136 & 190 & 299 \\
\hline & Gas consumption (Heating) & $\mathrm{m}^{3} / \mathrm{h}$ & 11.6 & 31.6 & 94.7 & 158 & 221 & 347 \\
\hline \multirow{6}{*}{ Electric supply } & Absorbent pump & $\mathrm{kW}$ & 0.75 & 2.25 & \multicolumn{2}{|c|}{3.7} & 7.5 & 9.2 \\
\hline & Refrigerant pump & $\mathrm{kW}$ & 0.1 & 0.15 & 0.2 & & 0.3 & \\
\hline & Purge pump & $\mathrm{kW}$ & 0.25 & \multicolumn{5}{|c|}{0.55} \\
\hline & Burner motor & $\mathrm{kW}$ & 0.25 & 0.75 & 3.0 & 4.0 & 7.5 & 11 \\
\hline & Total electric input & kVA & 3.7 & 5.5 & 9.6 & 10.8 & 16.1 & 17.1 \\
\hline & Power supply & & \multicolumn{6}{|c|}{$\begin{array}{c}415 \mathrm{~V}( \pm 10 \%) \\
50 \mathrm{~Hz}( \pm 5 \%), 3 \text { Phase }+\mathrm{N}\end{array}$} \\
\hline
\end{tabular}


Table (6) Hot water driven absorption chiller - technical specifications [9]

\begin{tabular}{|c|c|c|c|c|c|c|c|c|}
\hline \multirow{2}{*}{\multicolumn{2}{|c|}{ Nominal refrigeration capacity }} & NT.R. & 10 & 50 & 100 & 525 & 1000 & 1400 \\
\hline & & kW & 35 & 176 & 352 & 1848 & 3520 & 4928 \\
\hline \multirow[b]{2}{*}{$\begin{array}{l}\text { Chilled water } \\
\text { circuit }\end{array}$} & Flow rate & $\mathrm{m}^{3} / \mathrm{h}$ & 5.5 & 27.5 & 55 & 288.7 & 550 & 770 \\
\hline & $\begin{array}{l}\text { Inlet/ } \\
\text { Outlet temp. }\end{array}$ & ${ }^{\circ} \mathrm{C}$ & \multicolumn{6}{|c|}{$12.2 / 6.7$} \\
\hline \multirow{2}{*}{$\begin{array}{l}\text { Cooling water } \\
\text { circuit }\end{array}$} & Flow rate & $\mathrm{m}^{3} / \mathrm{h}$ & 10 & 50 & 100 & 525 & 1000 & 1400 \\
\hline & $\begin{array}{l}\text { Outlet/ Outlet } \\
\text { temp. }\end{array}$ & ${ }^{\circ} \mathrm{C}$ & \multicolumn{3}{|c|}{$29.4 / 36.7$} & \multicolumn{3}{|c|}{$29.4 / 36.8$} \\
\hline \multirow[b]{2}{*}{ Hot water circuit } & Flow rate & $\mathrm{m}^{3} / \mathrm{h}$ & 7.8 & 39.8 & 81 & 418 & 796 & 1115 \\
\hline & $\begin{array}{l}\text { Inlet/ } \\
\text { Outlet temp. }\end{array}$ & ${ }^{\circ} \mathrm{C}$ & \multicolumn{6}{|c|}{$90.6 / 85$} \\
\hline \multirow{5}{*}{ Electric supply } & Absorbent pump & $\mathrm{kW}$ & 0.3 & 0.55 & 1.5 & 3.0 & 7.5 & 9.2 \\
\hline & Refrigerant pump & $\mathrm{kW}$ & \multicolumn{2}{|c|}{0.3} & 0.3 & 1.5 & & \\
\hline & Purge pump & $\mathrm{kW}$ & \multicolumn{2}{|c|}{0.25} & \multicolumn{2}{|c|}{0.55} & & \\
\hline & $\begin{array}{l}\text { Total electric } \\
\text { input }\end{array}$ & kVA & 2.2 & 2.83 & 5.5 & 11.3 & 16.1 & 17.1 \\
\hline & Power supply & & \multicolumn{6}{|c|}{$\begin{array}{c}415 \mathrm{~V}( \pm 10 \%) \\
50 \mathrm{~Hz}( \pm 5 \%), 3 \text { Phase }+\mathrm{N}\end{array}$} \\
\hline
\end{tabular}


Table (7) Steam driven absorption chiller - technical specifications [9]

\begin{tabular}{|c|c|c|c|c|c|c|c|c|c|}
\hline \multirow{2}{*}{\multicolumn{3}{|c|}{ Nominal refrigeration capacity }} & \multirow{3}{*}{$\begin{array}{c}\text { NT.R. } \\
\mathrm{kW} \\
\mathrm{m}^{3} / \mathrm{h}\end{array}$} & \multirow{2}{*}{$\frac{100}{351}$} & \multirow{2}{*}{$\begin{array}{l}210 \\
737\end{array}$} & \multirow{2}{*}{$\frac{400}{1404}$} & \multirow{2}{*}{$\frac{620}{2176}$} & \multirow{2}{*}{$\frac{1050}{3686}$} & \multirow{2}{*}{$\frac{1400}{4914}$} \\
\hline & & & & & & & & & \\
\hline \multirow{2}{*}{\multicolumn{2}{|c|}{ Chilled water circuit }} & Flow rate & & 55 & 116 & 220 & 341 & 578 & 770 \\
\hline & & Inlet/ Outlet temp. & ${ }^{\circ} \mathrm{C}$ & \multicolumn{6}{|c|}{$12.2 / 6.7$} \\
\hline Cooling water & \multirow{9}{*}{ 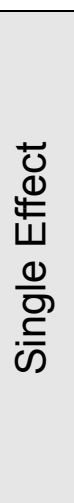 } & Flow rate & $\mathrm{m}^{3} / \mathrm{h}$ & 90.7 & 190 & 363 & 562 & 952 & 1270 \\
\hline circuit & & Outlet/ Outlet temp. & ${ }^{\circ} \mathrm{C}$ & \multicolumn{6}{|c|}{$29.4 / 36.8$} \\
\hline \multirow{2}{*}{ Steam circuit } & & Steam consumption & $\mathrm{Kg} / \mathrm{h}$ & 830 & 1750 & 3320 & 5150 & 8720 & 11620 \\
\hline & & Steam pressure & $\mathrm{kg} / \mathrm{cm}^{2} \mathrm{~g}$ & \multicolumn{6}{|c|}{1.5 saturated } \\
\hline \multirow{5}{*}{ Electric supply } & & Absorbent pump & $\mathrm{kW}$ & \multicolumn{2}{|c|}{1.5} & \multicolumn{2}{|c|}{3.0} & 4.5 & 5.5 \\
\hline & & Refrigerant pump & $\mathrm{kW}$ & \multicolumn{4}{|c|}{0.3} & \multicolumn{2}{|c|}{1.5} \\
\hline & & Purge pump & $\mathrm{kW}$ & & 0.37 & & \multicolumn{3}{|c|}{0.55} \\
\hline & & Total electric input & kVA & \multicolumn{2}{|c|}{5.9} & 8.25 & 8.45 & 14.1 & 17.6 \\
\hline & & Power supply & & \multicolumn{6}{|c|}{$\begin{array}{c}415 \mathrm{~V}( \pm 10 \%) \\
50 \mathrm{~Hz}( \pm 5 \%), 3 \text { Phase }+\mathrm{N}\end{array}$} \\
\hline \multirow{2}{*}{$\begin{array}{c}\text { Cooling water } \\
\text { circuit }\end{array}$} & \multirow{9}{*}{ 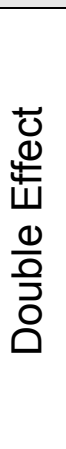 } & Flow rate & $\mathrm{m}^{3} / \mathrm{h}$ & 90 & 189 & 360 & 496 & 840 & 1120 \\
\hline & & Outlet/ Outlet temp. & ${ }^{\circ} \mathrm{C}$ & \multicolumn{3}{|c|}{$29.4 / 35.5$} & \multicolumn{3}{|c|}{$29.4 / 36.2$} \\
\hline \multirow{2}{*}{ Steam circuit } & & Steam consumption & $\mathrm{Kg} / \mathrm{h}$ & 430 & 903 & 1720 & 2604 & 4410 & 5880 \\
\hline & & Steam pressure & bar $g$ & \multicolumn{6}{|c|}{8 saturated } \\
\hline \multirow{5}{*}{ Electric supply } & & Absorbent pump & $\mathrm{kW}$ & 2.2 & 3.0 & 3.7 & 5.5 & 7.5 & 9.0 \\
\hline & & Refrigerant pump & $\mathrm{kW}$ & \multicolumn{4}{|c|}{0.3} & \multicolumn{2}{|c|}{1.5} \\
\hline & & Purge pump & kW & \multicolumn{4}{|c|}{0.37} & \multicolumn{2}{|c|}{0.75} \\
\hline & & Total electric input & kVA & 7.1 & & & 13.2 & 20.8 & 27.2 \\
\hline & & Power supply & & & & & $5 \%), 3$ & $\mathrm{se}+\mathrm{N}$ & \\
\hline
\end{tabular}


Table (8) Capital cost of various types of absorption chillers

\begin{tabular}{|l|c|c|c|c|c|}
\hline \multicolumn{1}{|c|}{ Chiller Capacity, R.T. } & \multicolumn{5}{|c|}{ Installed Cost, \$/ton } \\
\cline { 2 - 6 } & 100 & 300 & 500 & 750 & 1000 \\
\hline $\begin{array}{l}\text { Double-effect direct-fired } \\
\text { absorption [10] }\end{array}$ & \multicolumn{5}{|c|}{625} \\
\hline $\begin{array}{l}\text { Single-effect hot water-heated } \\
\text { absorption [11] }\end{array}$ & 1,075 & 850 & 680 & 650 & 620 \\
\hline $\begin{array}{l}\text { Single-effect steam-heated } \\
\text { absorption [12] }\end{array}$ & 625 & 520 & 430 & 390 & 365 \\
\hline $\begin{array}{l}\text { Double-effect steam-heated } \\
\text { absorption }\end{array}$ & 875 & 730 & 600 & 540 & 510 \\
\hline
\end{tabular}




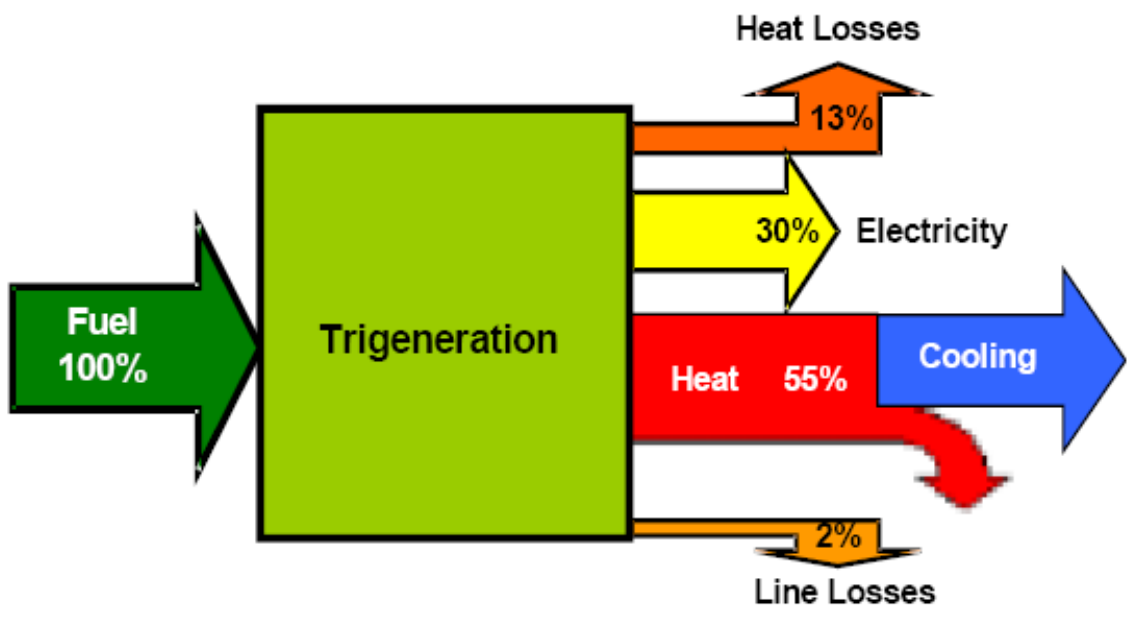

Figure 1. Tri-generation principle.

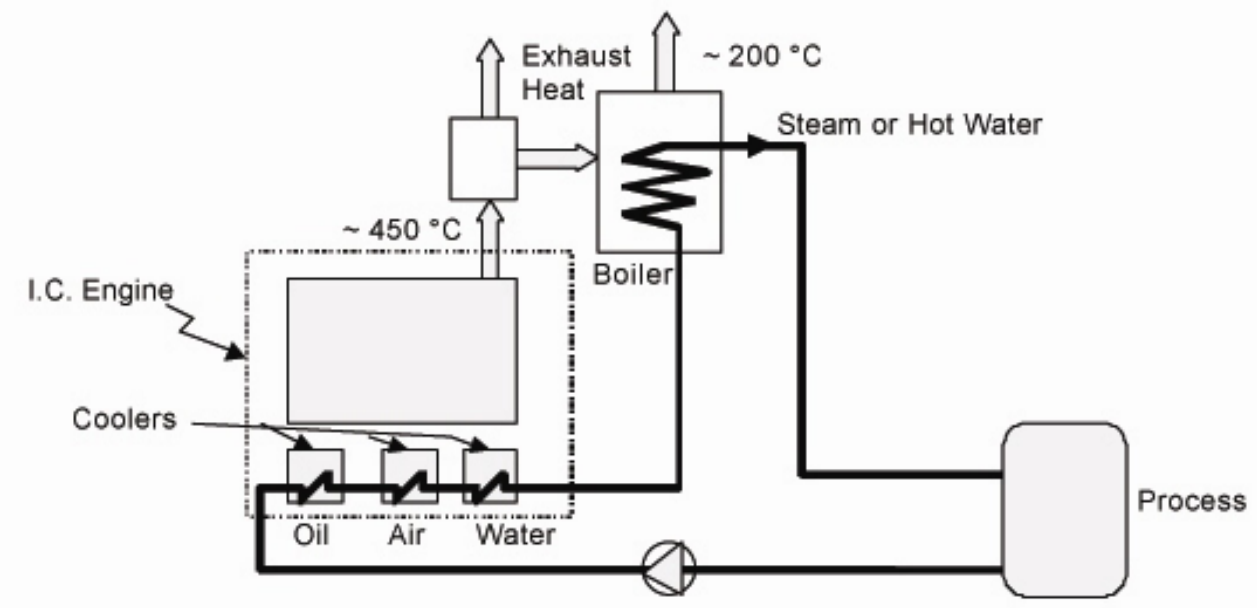

Figure 2 Schematic diagram of reciprocating engine cogeneration 


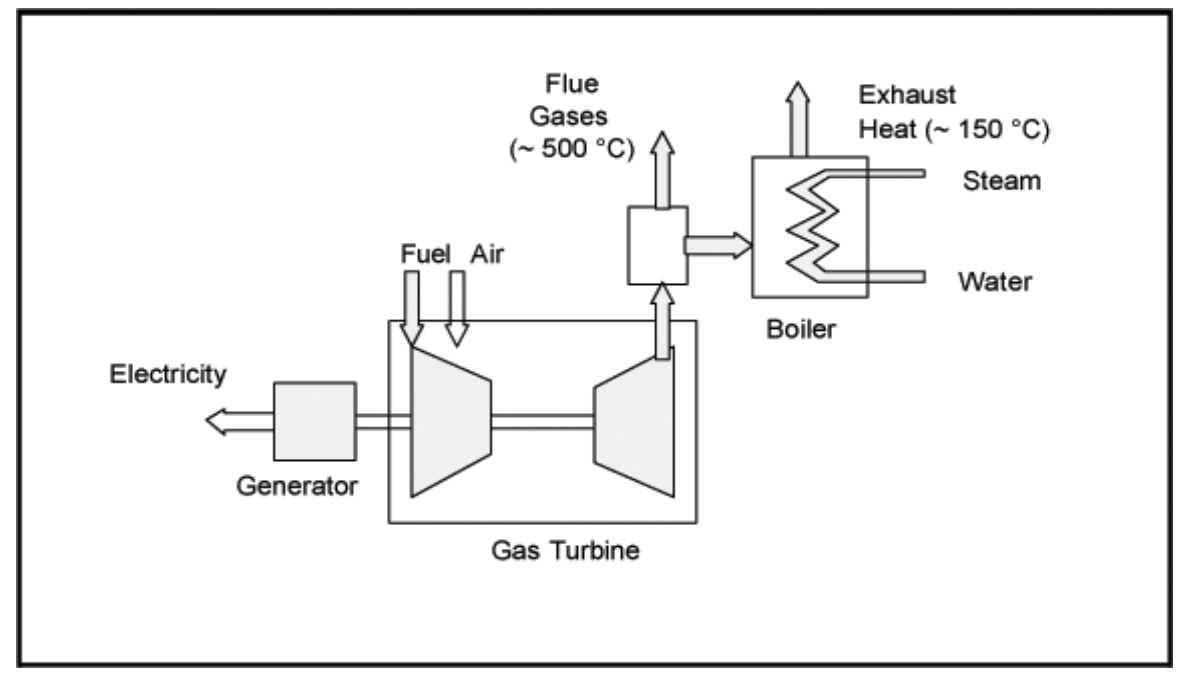

Figure 3 Schematic diagram of gas turbine cogeneration.

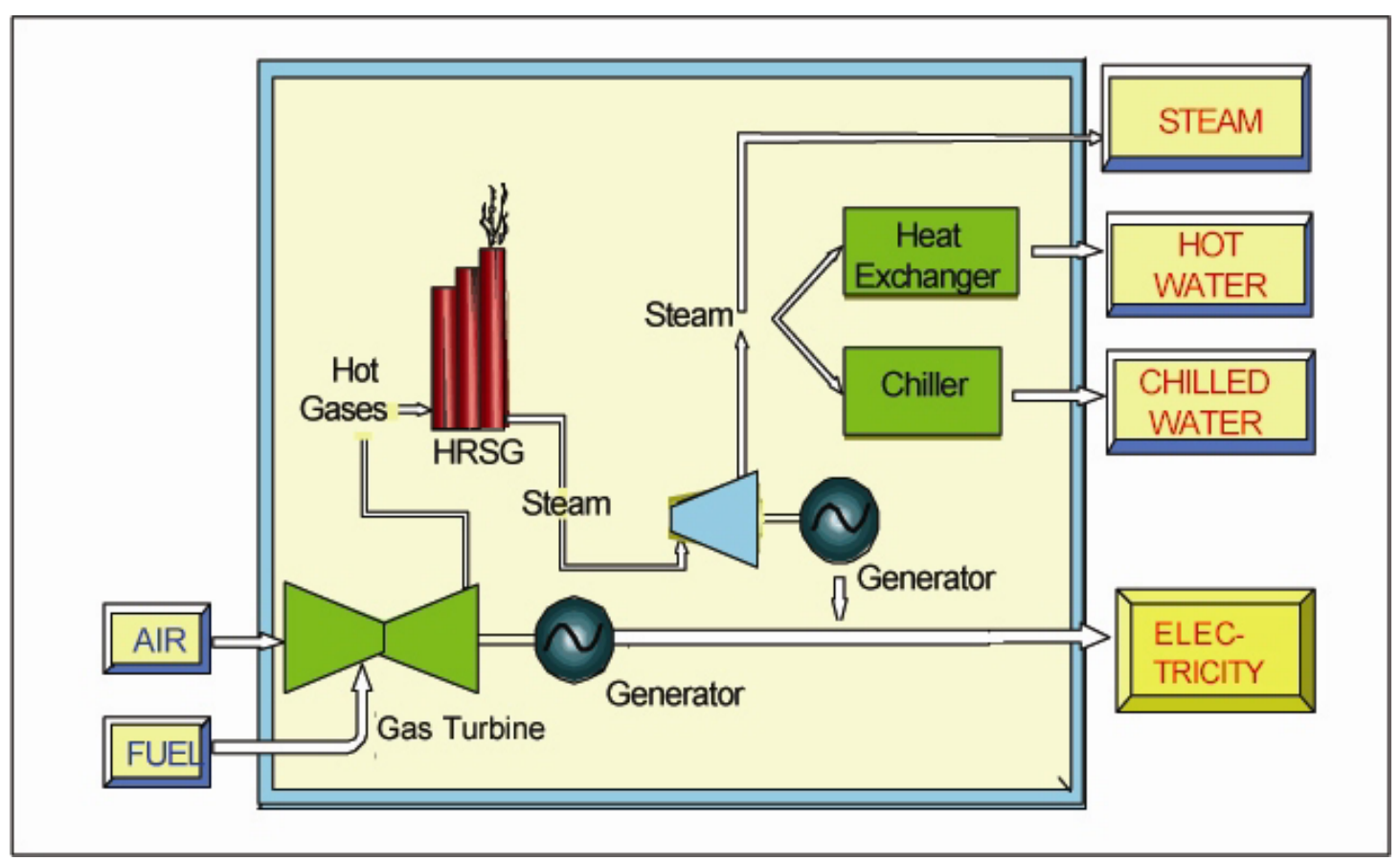

Figure 4 Schematic presentation of a gas turbine based trigeneration facility 


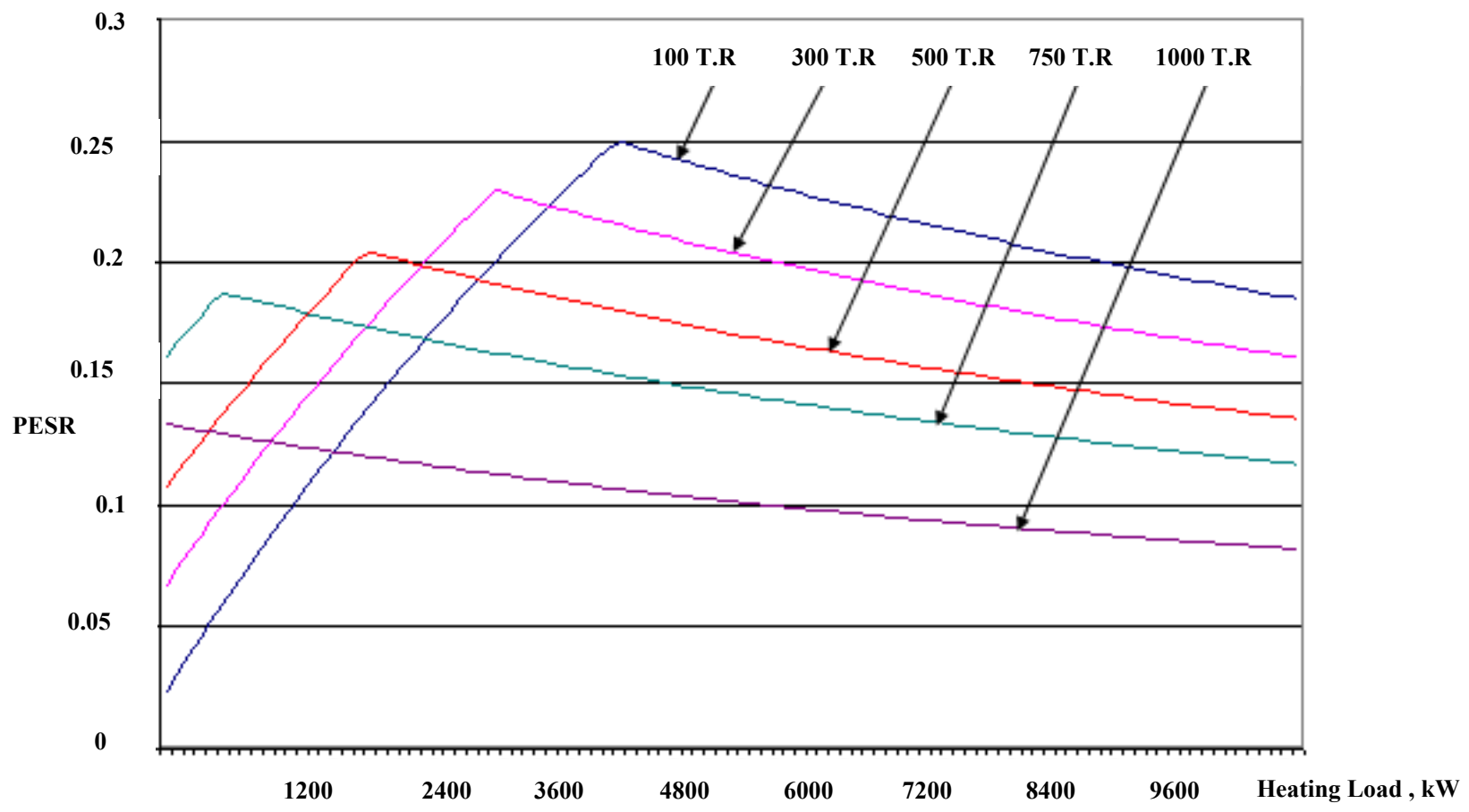

Fig.5 Variation of the primary energy saving ratio (PESR) with the heating load for different values of cooling loads for the tri-generation arrangement with electric load of $5000 \mathrm{~kW}$.

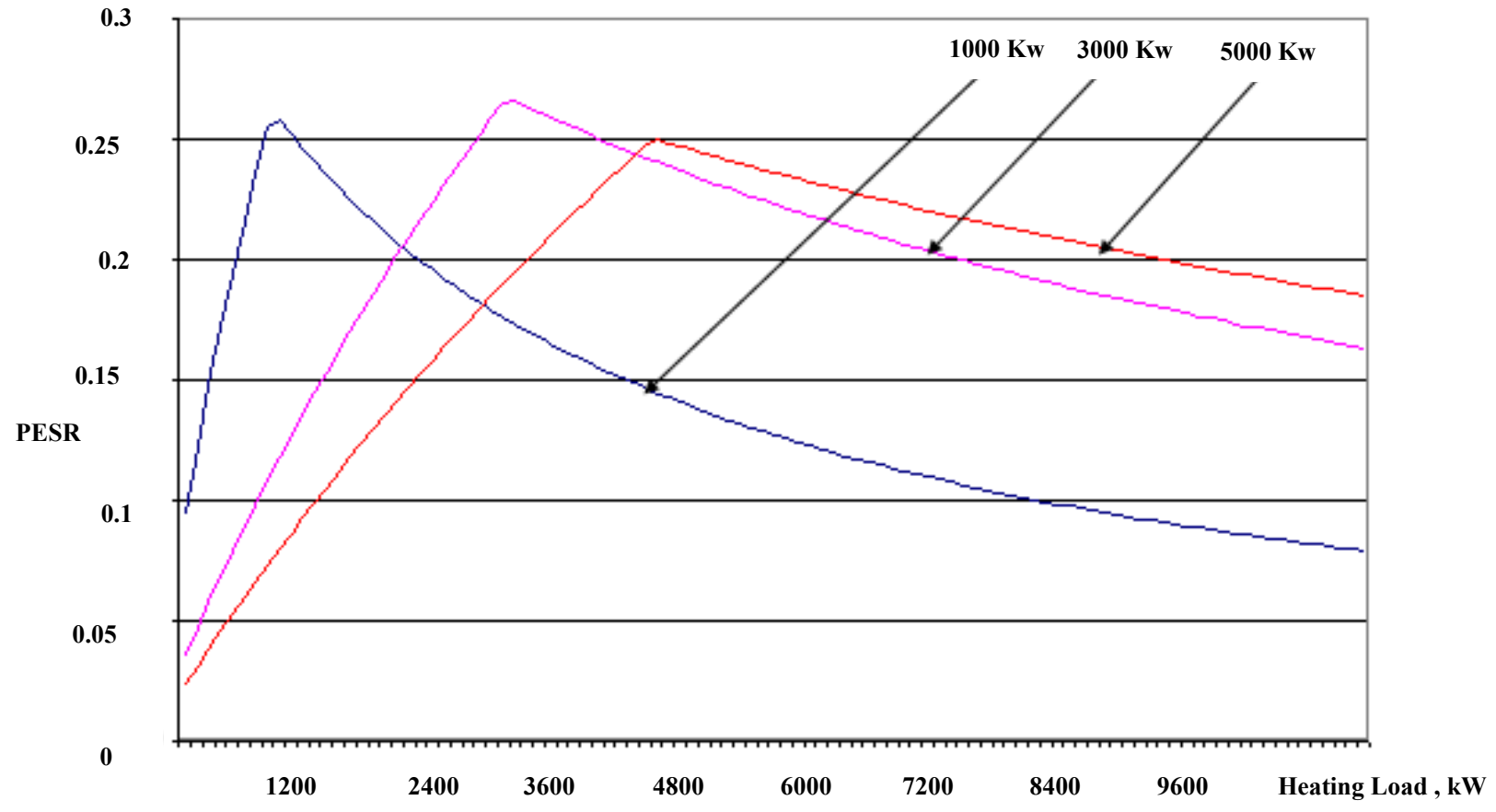

Fig. 6 Variation of the heating load with the PERS for different values of the electric load with constant value of cooling load of 100 T.R for tri-generation arrangement. 


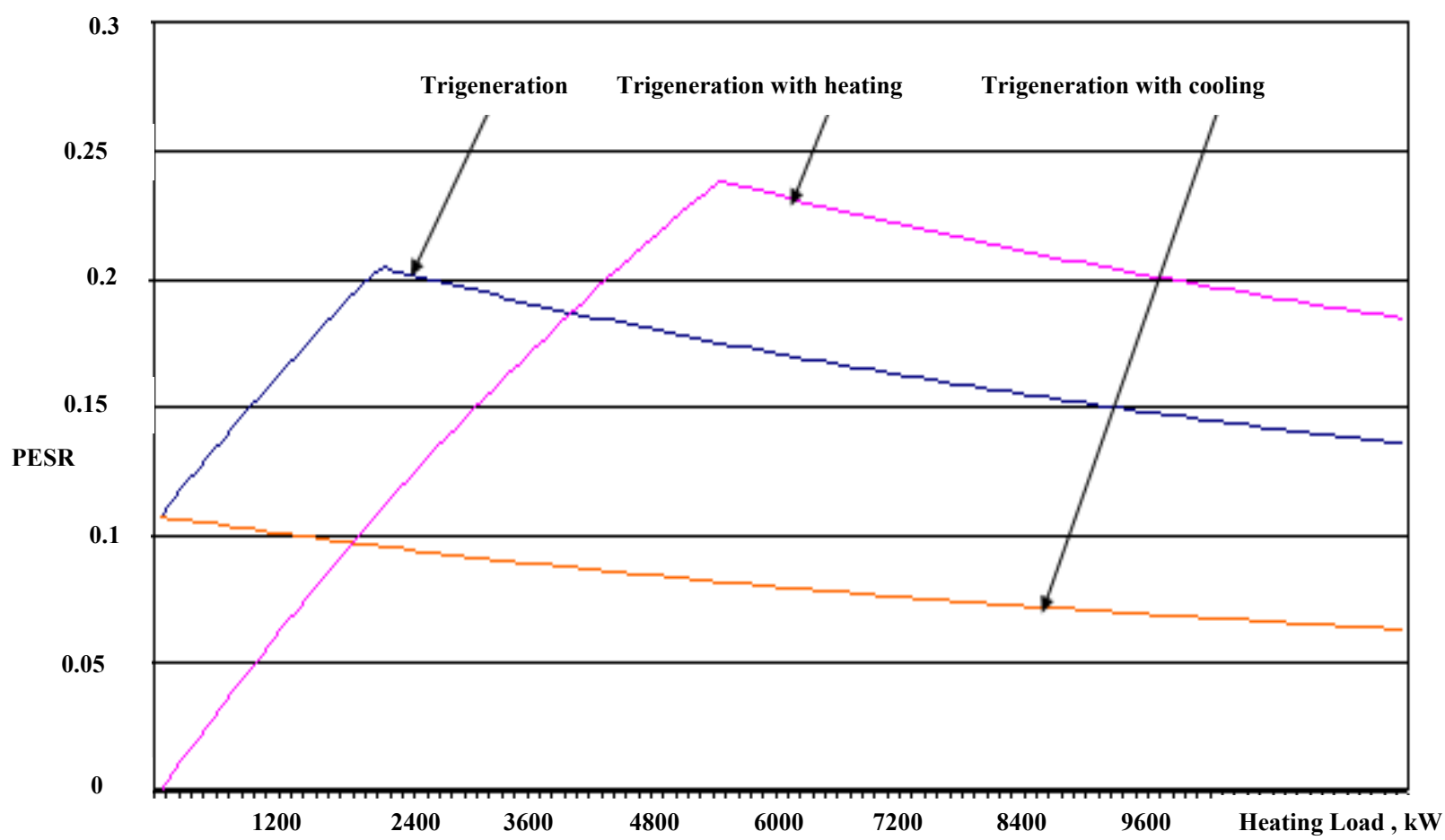

Fig. 7 Variation of PESR with the heating load for the different arrangements at $5000 \mathrm{~kW}$ electric power and 500 T.R

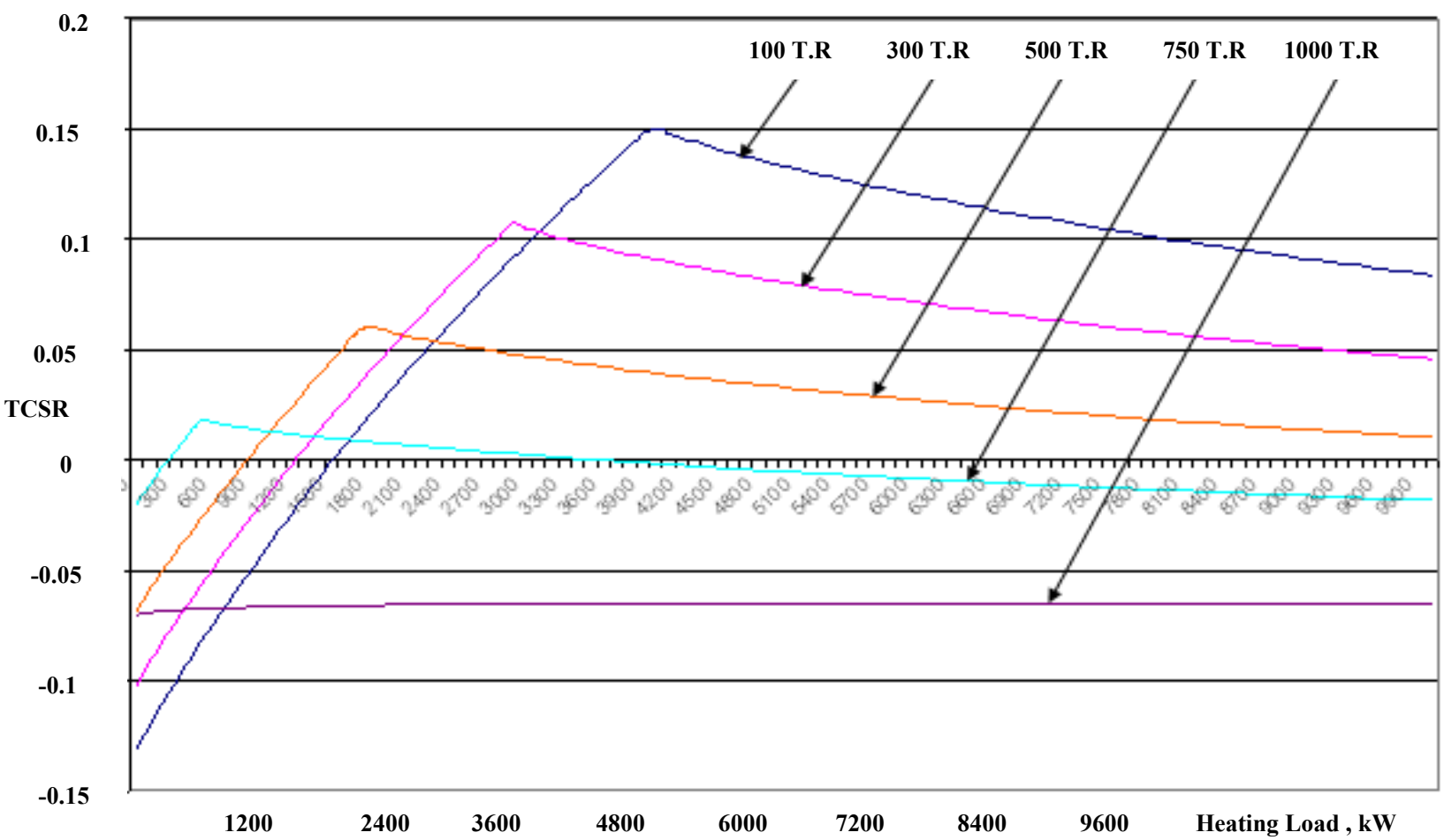

Fig. 8 Variation of the total cost saving ratio (TCSR) with the heating load for different values of cooling loads for the tri-generation arrangement with electric load of $5000 \mathrm{~kW}$. 


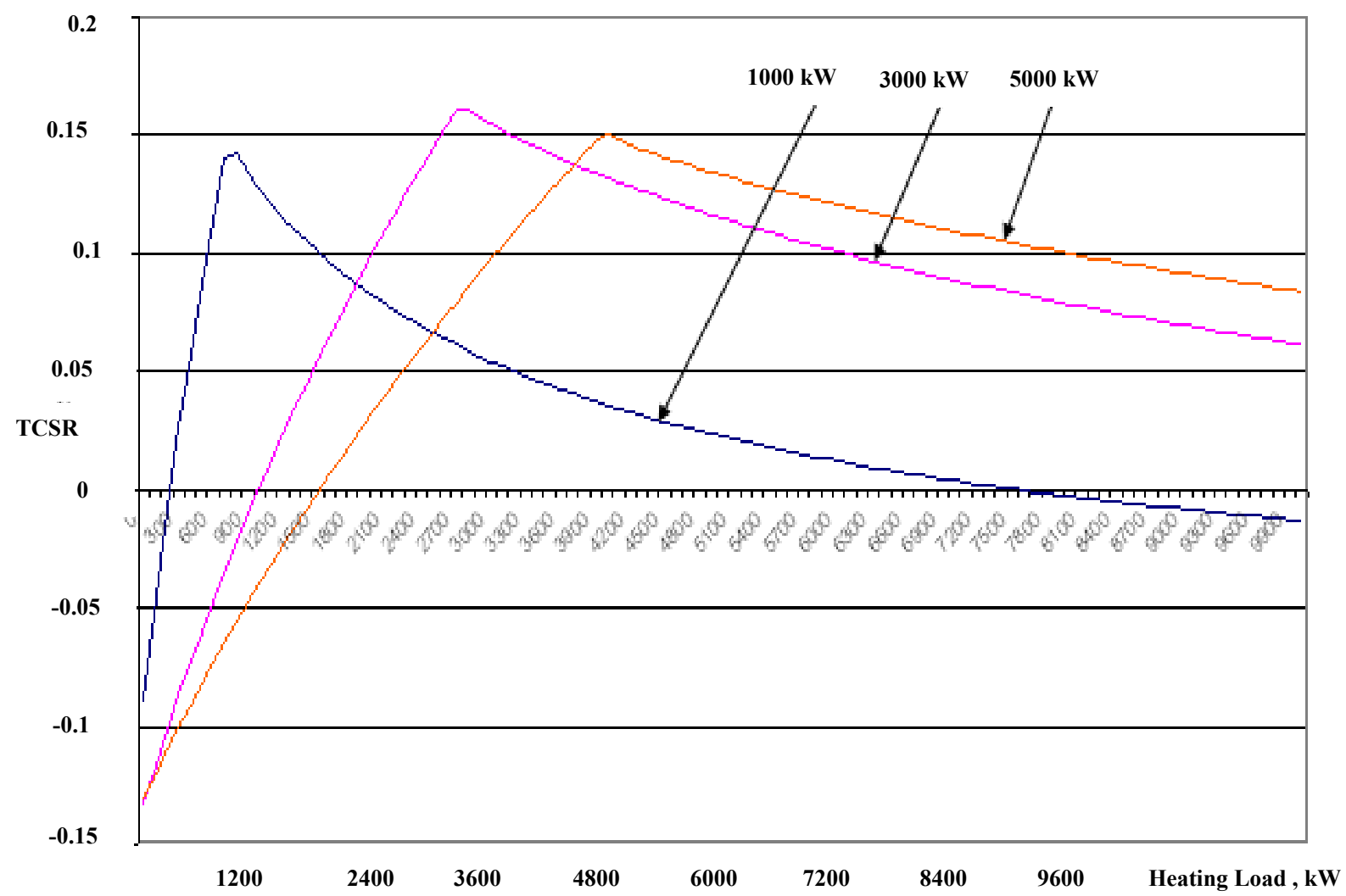

Fig. 9 Variation of the heating load with the TCSR for different values of the electric load with constant value of cooling load of 100 T.R. for tri-generation arrangement.

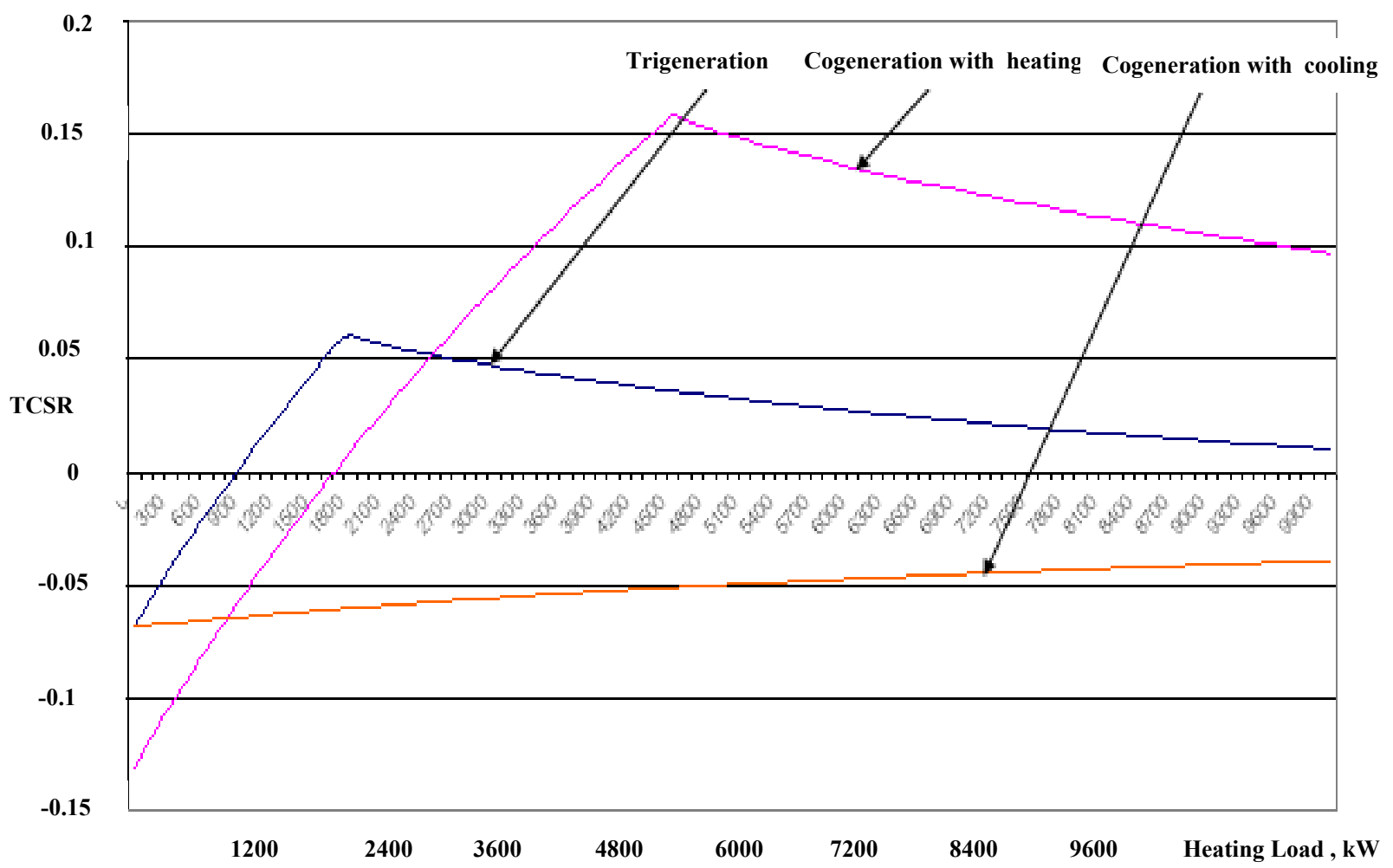

Fig. 10 Variation of total cost saving ratio (TCSR) with the heating load for the different arrangements at 5000 kW electric power and 500 T.R. 


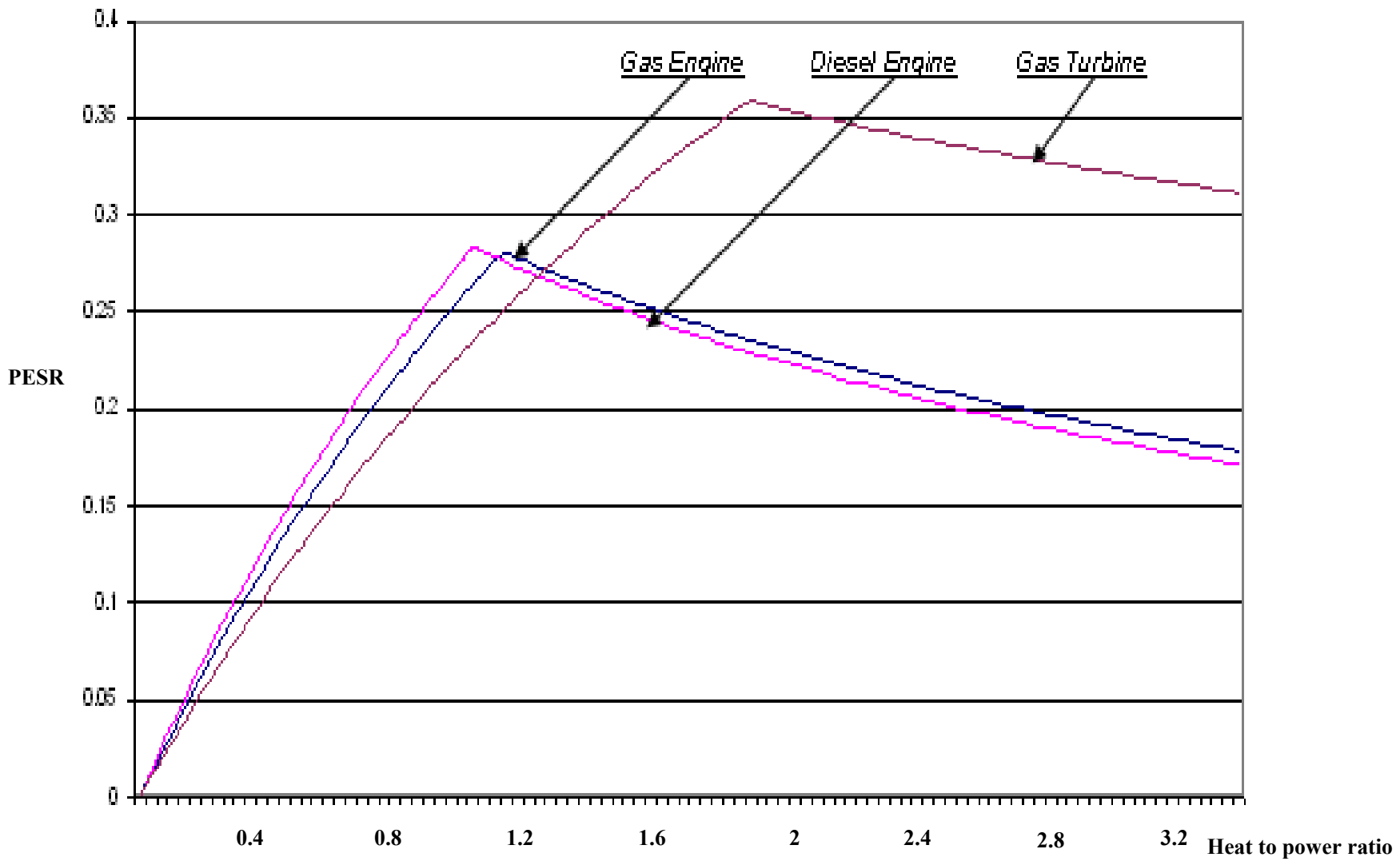

Fig. 11 Variation of PESR with the heat to power ratio for different prime moves with electric load $3000 \mathrm{~kW}$.

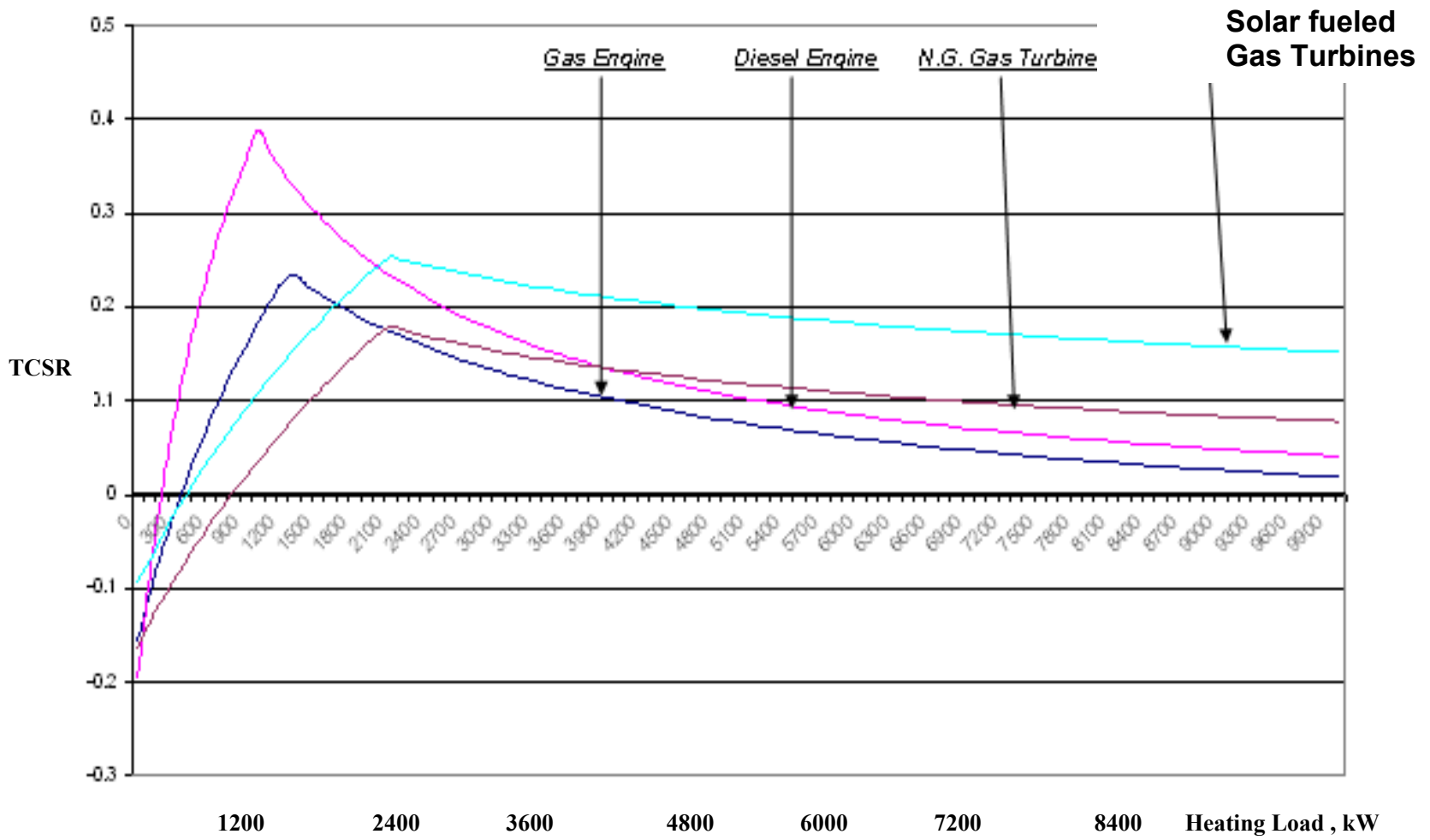

Fig. 12 Variation of the (TCSR) with the heat load for different prime movers for an electric load of $1000 \mathrm{~kW}$ with 8000 hours per year. 


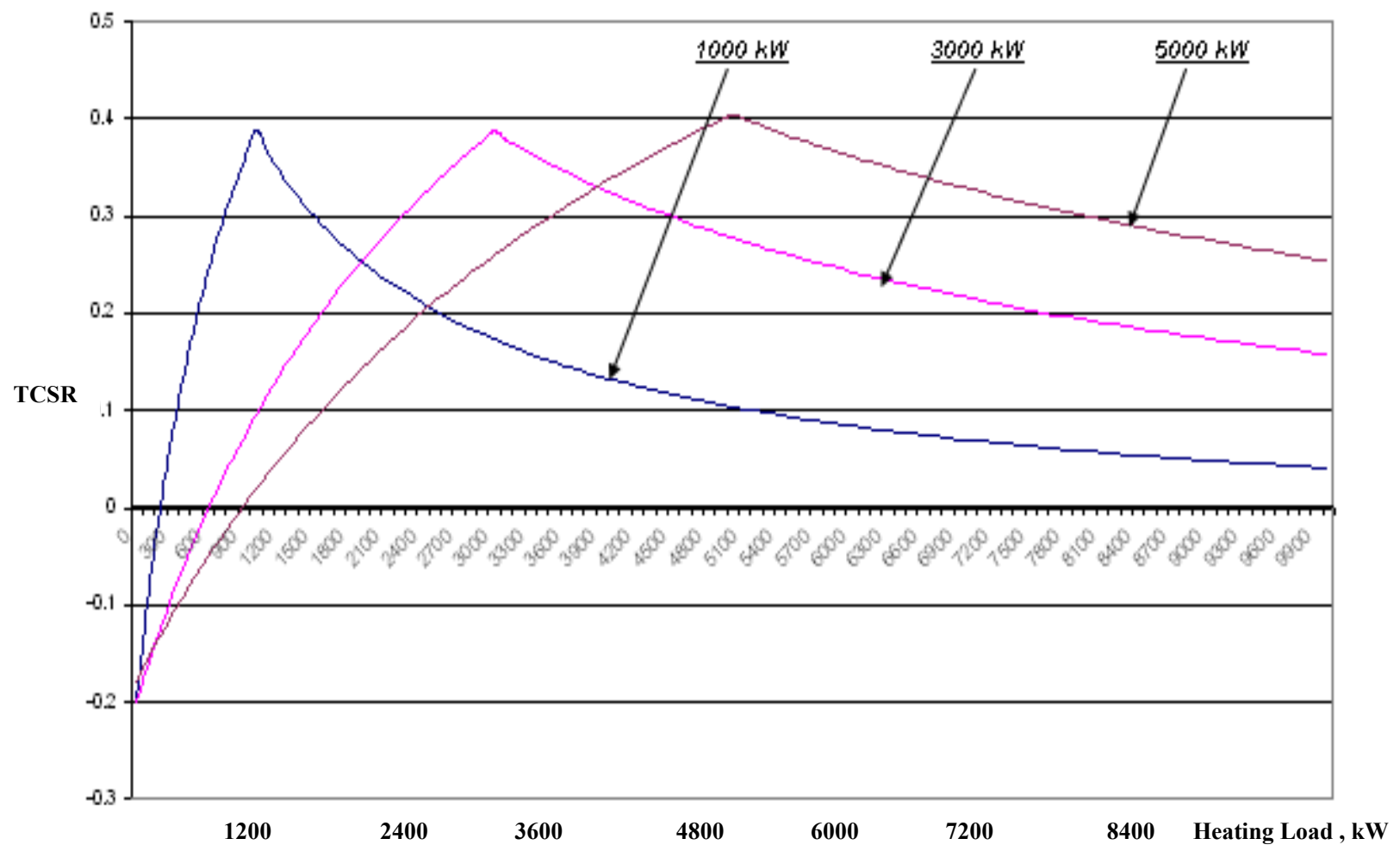

Fig. 13 Variation of the heat recovery with the TCSR for different values of the electric loads for diesel engine.

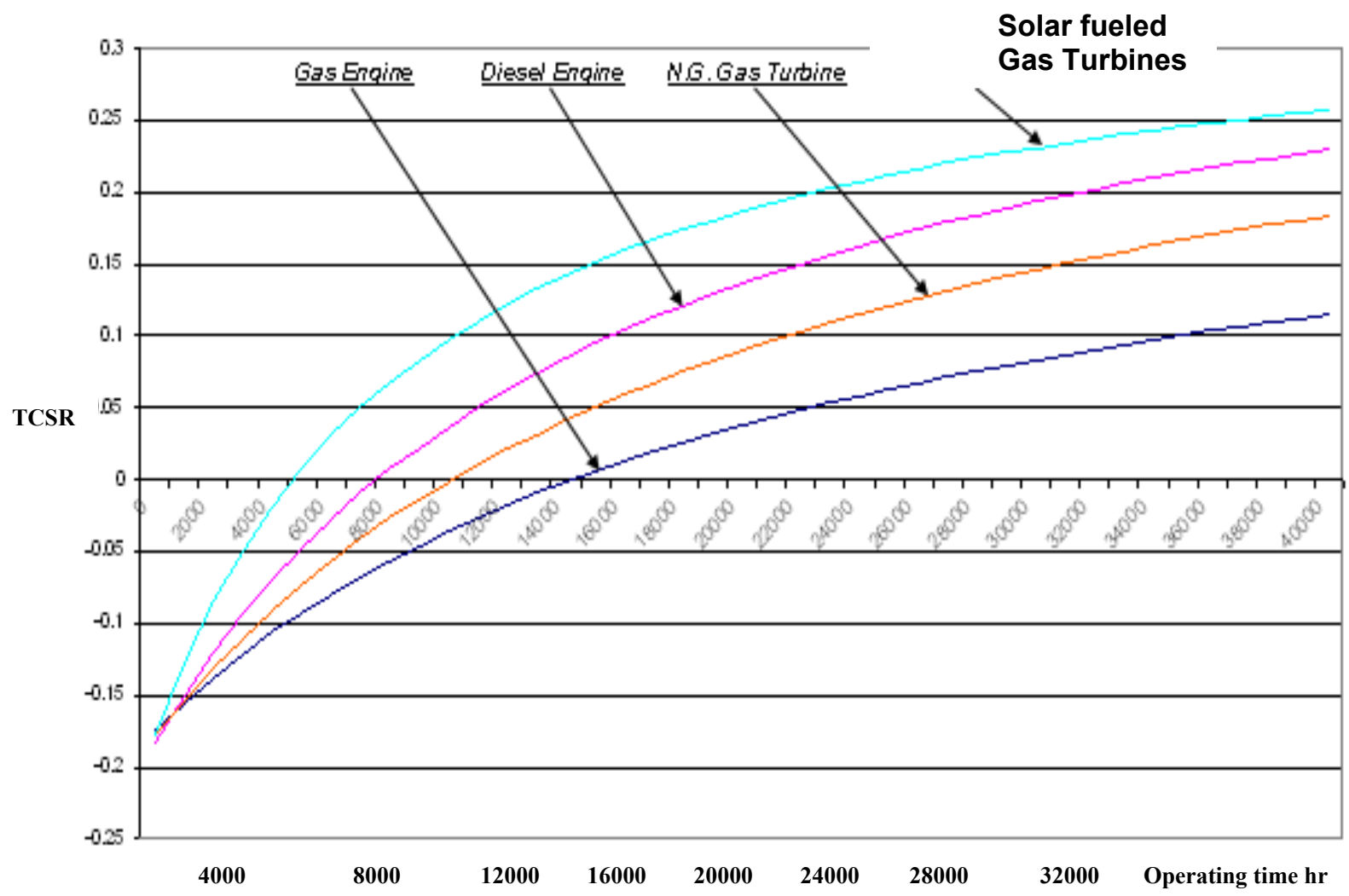

Fig. 14 Variation of the TCSR with the number of hours of operation for different prime movers and a cooling load of 100 T.R, an electric load of $3000 \mathrm{~kW}$ and a heating load of $5000 \mathrm{~kW}$. 